\title{
Viewpoint: Alternative dispute resolution in public land management
}

\author{
DAVID J. TORELL
}

Author is extension educator, Cooperative Extension, University of Nevada, Reno.

\begin{abstract}
Alternative dispute resolution is a concept of dispute settlement which uses techniques other than litigation to reduce or resolve conflict. It involves bringing together parties in disagreement to participate in joint decision-making processes which seek win/win solutions. Alternative dispute resolution processes maintain control and authority for agreement in the hands of the parties in dispute. A third party process person is commonly utilized to assist parties in resolving conflicts.

The application of alternative dispute resolution techniques in the field of natural resource management is relatively new. A study of environmental disputes found that $78 \%$ of the cases where alternative dispute resolution techniques were used, resulted in settlement.

There are limitations and benefits to the application of these techniques in the fleld of natural resource management. Widespread use requires a significant increase in the understanding of alternative dispute resolution concepts and application among natural resource professionals.
\end{abstract}

Key Words: alternative dispute resolution, conflict resolution, group process, land planning

The world is preoccupied with litigation as a primary method of resolving disputes. Chief Justice Warren E. Burger quoted Abraham Lincoln as saying, "Our distant forebears moved slowly from trial by battle and other barbaric means of resolving conflicts and disputes, and we must move away from total reliance on the adversary contest for resolving all disputes. For some disputes, trials by an adversarial contest must, in time, go the way of the ancient trial by battle and blood. Our system is too costly, too painful, too destructive, too inefficient for truly civilized people. To rely on the adversarial process as the principal means of resolving conflicting claims is a mistake that must be corrected" (Priscoli 1984).

Public land management agencies are heavily burdened with litigated measures between resource uses and environmental protection. Subjects such as stream flows for agriculture and fisheries habitat, Threatened and Endangered species, livestock grazing on public lands, and wildlife populations are common issues of dispute. Such is the case of Wayne Hage versus the United States Forest Service, where litigation is centered between Forest plan implementation and the "Takings" of private property.

Litigated actions have proven to be costly and time consuming for many of the parties involved in natural resource management. Public land managers report that decisions reached through litigation often result in little positive impact upon natural resource concerns. Appeals and counter suits frequently extend conflicts for long periods of time. As such, an alternative strategy for resolving

Manuscript accepted 12 Jun. 1993. natural resource conflicts is needed.

Alternative dispute resolution (ADR) processes hold great potential of providing an alternative to litigation. Alternative dispute resolution centers on the belief that effective agreements involve cooperation and interest-based problem solving among parties involved in a dispute. While litigation and other decisionmaking processes are of value, alternative dispute resolution provides a means of off-loading the increasing pressure on the legal system. Alternative dispute resolution has proven to be effective at resolving conflicts in $78 \%$ of the cases where parties voluntarily participate in a consensus problem-solving process (Bingham 1986).

While alternative dispute resolution is somewhat limited in its use at this time, Public Land Managers are becoming more interested in its concepts. The social and behavioral sciences of alternative dispute resolution are new and rapidly developing. In addition they are poorly understood by many of the professionals in range management. This is no fault of the range management profession, but is the result of a changing paradigm in range management.

In Nevada alternative dispute resolution concepts have been applied in Forest Service land planning sessions where Riparian Habitat restoration and Endangered Lahontan Cutthroat Trout populations have been issues of controversy. Forest service employees and ranchers have reported that alternative dispute resolution processes improved the efficiency and ability of conflicting groups to work out solutions to these issues.

Based upon the signs of change, alternative dispute resolution stands to be a major part of range management in the future. This article examines the benefits, obstacles, and procedures of alternative dispute resolution.

\section{Concepts of Alternative Dispute Resolution}

Alternative dispute resolution is a conflict resolution process which uses techniques other than those of litigation. These techniques favor joint decision making with control of the negotiation process in the hands of the parties in dispute. The use of third party facilitation is common among alternative dispute resolution techniques. The approach is voluntary in nature and seeks win-win strategies.

Table 1 , outlines a general continuum of alternative dispute resolution procedures that may be applicable in public land management. This continuum ranges from the left with cooperative decision making, to the middle with Third Party assistance, to the right with third party decision making. Most of the procedures have some form of relationship building, procedural and substantive assistance, or counseling as a means of facilitating agreement. They differ in the degree and emphasis of assistance provided.

An examination of the Alternative Dispute Resolution continuum (Table 1) brings to the forefront, 4 points that deserve discussion: 
Table 1. A continuum of alternative dispute resolution procedures.

\begin{tabular}{|c|c|c|c|c|c|}
\hline \multirow{2}{*}{$\begin{array}{l}\text { Cooperative decision } \\
\text { Parties are } \\
\text { unassisted }\end{array}$} & \multicolumn{3}{|c|}{ Third party assistance with negotiations or } & \multicolumn{2}{|c|}{ Third party decision making } \\
\hline & $\begin{array}{l}\text { Relationship building } \\
\text { assistance }\end{array}$ & $\begin{array}{l}\text { Procedural } \\
\text { assistance }\end{array}$ & $\begin{array}{l}\text { Substantive } \\
\text { assistance }\end{array}$ & $\begin{array}{l}\text { Advisory non-binding } \\
\text { assistance }\end{array}$ & $\begin{array}{l}\text { Binding } \\
\text { assistance }\end{array}$ \\
\hline $\begin{array}{l}\text { *Conciliation } \\
\text { *Information } \\
\text { Exchange } \\
\text { Meetings } \\
\text { *Cooperative/ } \\
\text { Collaborative } \\
\text { Problem } \\
\text { Solving } \\
\text { *Negotiations }\end{array}$ & $\begin{array}{l}\text { *Counseling/ } \\
\text { Therapy } \\
\text { *Conciliation } \\
\text { *Team } \\
\text { Building } \\
\text { *Informal } \\
\text { Social } \\
\text { Activities }\end{array}$ & $\begin{array}{l}\text { *Coaching/ } \\
\text { Process } \\
\text { Consultation } \\
{ }^{*} \text { Training } \\
\text { *Facilitation } \\
\text { *Mediation }\end{array}$ & $\begin{array}{l}\text { *Mini-Trial } \\
\text { *Technical } \\
\text { Advisory } \\
\text { Boards/ } \\
\text { Disputes Panels } \\
\text { *Advisory } \\
\text { Mediation } \\
\text { *Fact Finding } \\
\text { *Settlement } \\
\text { Conference }\end{array}$ & $\begin{array}{l}\text { *Non-Binding } \\
\text { Arbitration } \\
\text { *Summary } \\
\text { Jury Trial }\end{array}$ & $\begin{array}{l}\text { *Binding } \\
\text { Arbitration } \\
\text { *Med-Arb } \\
\text { *Mediation- } \\
\text { then-Arbi- } \\
\text { tration } \\
\text { *Disputes } \\
\text { Panels } \\
\text { (binding) } \\
\text { *Private } \\
\text { Courts/judging }\end{array}$ \\
\hline
\end{tabular}

Source: Moore and Priscoli (1989)

1) As alternative dispute resolution procedures move from cooperative decisions to third party decision making, they gradually give more power and authority to resolve disputes to a third party.

2) The basic principles and procedures of interest-based negotiations can be applied to any technique along the continuum.

3) New procedures of alternative dispute resolution will be developed as public planning activities use more alternative dispute resolution concepts.

4) As stated by Moore and Priscoli (1989), "It is important to remember all communication in disputes contains both content and process. Very often, the way we talk or the process of dialogue will determine how and if people listen to the content of the dialogue. The major premise behind alternative dispute resolution techniques is that by separating the process of dialogue from the content of dialogue in a dispute, we can better manage the discussions and promote agreement. This separation of process and content is what leads to the use of the third parties, sometimes called "interveners". These third parties, in various ways, become caretakers of the dialogue process in disputes."

This situation has occurred in Nevada in cases where ranchers and environmentalists have attemped to communicate during allotment management planning sessions with land management agencies. Interveners successfully reduced and avoided disputes in planning meetings by managing the dialogue process while participants focused their attention on the content of dialogue. The result was participants reported increased satisfaction in the planning process because of the role of the intervener.

\section{Benefits and Obstacles of Alternative Dispute Resolution in Public Land Management}

Priscoli (1986) identified numerous advantages of alternative dispute resolution processes. Understanding the advantages will help Public Land Managers know where to use these concepts in solving public land conflicts. Some of the more significant benefits in public land management are:

1) Getting better decisions-Many public land management decisions are challenged by interested parties because proposed decisions are seen as not satisfying real interests. Agreements that satisfy real interest of parties in a dispute improve the level of satisfaction with the decision. Through alternative dispute resolution, the parties are involved in deciding acceptable alternatives in an agreement. In court actions it is generally an all-or-nothing decision decided by a judge. Once again, as reported by Bingham (1986), the quality of decisions reached through alternative dispute resolution techniques that have resulted in higher levels of satisfaction in decisions reached in $78 \%$ of the cases studied.

2) Creating a better climate for resolution-Alternative dispute resolution processes are voluntary, the participants are involved because they believe that they can generate a more acceptable agreement. In alternative dispute resolution techniques, a better environment for communications and sharing of information often exists. Individuals within the group are more prone to move from positional bargaining to problem solving when they feel their needs and values are seriously considered and valued in the process. As a result a greater probability of resolving disputes exists.

3) Expediting procedures-Initial investments in the alternative dispute resolution process may be high. However, sustainable solutions to disputes demand that parties trust and are committed to decisions reached during negotiations. When they are not, total time invested in a dispute is lengthened and the probability of impiementing decisions are reduced. Through alternative dispute resolution techniques, the parties controlling the process can schedule meetings at their discretion and make decisions when they are ready.

4) Reducing costs-Alternative dispute resolution processes usually involve a third party mediator or negotiator but this is not always the case. Costs for these services are much lower than lawyer and court expenses.

5) Enhancing flexibility - The parties in a dispute decide how they will operate, what criteria they will use to reach agreement and if they will reach agreement. They may agree to not agree, but they make the decisions. This adds substantial flexibility to the process.

6) Providing more control over the outcome-Decision-making authority is retained by the parties in dispute, therefore they retain the authority to decide, whereas in litigation a judge or arbitrator makes the decision.

7) Encouraging control by people who know the organization's needs best-Alternative dispute resolution seeks to put control in the hands of the people who are best able to assess the impacts of any proposed decision and have the flexibility of developing creative solutions. When they have control they have a greater incentive and motivation to move toward agreement.

8) Increasing the probability that decisions will hold up-When the parties involved in a dispute share in the authority to make decisions, they have greater interest in making an agreement work. Mutual agreements are more likley to hold up over time and prevent future problems.

Lancaster et al. (1990), identified obstacles to the application of 
alternative dispute resolution processes. These obstacles must be managed before alternative dispute resolution will be widely used in the management of public lands. Some of the major obstacles and solutions are:

1) Tradition/agency culture which favors the usual way of doing business-Public land managers and interested parties may have a mindset which prefers the known processes of litigation rather than the unknown risks of alternative dispute resolution. They may be resistant to new roles and procedures. Perceptions that alternative dispute resolution is a soft or "giving in" approach to conflict may prevail among some individuals. Some may feel threatened by a giving of power to others in the decision-making process. Still, others may be hesitant to take risk.

\section{Solution:}

These obstacles can be overcome through training and greater familiarity with alternative dispute resolution processes. Clarity between alternative dispute resolution and the National Environmental Protection Act (NEPA) will prevent confusion. Experience and successful models will generate comfort with alternative dispute resolution's use. Leadership and promotion of alternative dispute resolution from agency heads and interest groups will create a greater acceptance of alternative dispute resolution. Policies which require or suggest alternative dispute resolution as an alternative or intermediate step to litigation will be helpful.

2) Lack of incentives and authority to settle disputes in existing planning approaches -Existing public land planning activities typically promote positional bargaining among opposing interests. Agency personnel and interest group representatives involved in many planning processes do not hold authority to settle disputes or make decisions. They frequently only hold authority to represent a position of the group. Their involvement centers around bargaining their position. Agreement can only be reached if they obtain an, "all position" agreement from the other side(s). They must go back to some other authority in their group to gain authority to agree with a suggested solution. This is a win/lose positional process. It often ends in litigation.

Solution: Land management agencies and special interest groups can allow responsibility and authority for settlement at the local level or organizational level. This will allow those actually working on the resource to have the authority to make decisions. Policies and guidelines can be set with flexibility in how they are to be met. Organizations can promote the reality of costs and delays caused by litigation and demonstrate a real desire to solve problems and manage natural resources, beyond political caucusing.

3) Professional vanity: unwillingness to allow others to share in decision making authority -Some professional are insecure about the ability of others to make good decisions and to hold power. Some even resist settlement for fear that there might be some unknown benefit of the decision to the opposition. Both policy and personnel tend to protect power retention even at the demise of problem solving and on-the-ground resource management. As such, power management tends to dominate the strategy of many public land planning processes. Focus is placed on position and power during planning activities rather than problem solving and resource well-being.

\section{Solution:}

Incentives can be developed which offer rewards for settlements outside of more costly processes. Incentives can focus on problem solving results and applications of agreement. Policies and reward systems can reduce the threats and risks to people and reputations.

4) Lack of trust: Historical experiences and perceptions influence the willingness of participants to trust others in public land planning. Consequently, solutions to problems are often dismissed without being adequately considered when presented by an opposing side.

\section{Solution:}

Public land planning activities can involve more teambuilding and partnering activities. Emphasis and institutionalization of alternative dispute resolution processes can help to recognize and reward successful uses of alternative dispute resolution. Top management participation and support can generate trust within organizations.

5) The need to justify the alternative dispute resolution settlement with procedural requirements-NEPA and other documents outline procedural guidelines that must be followed during public land planning. In addition, planning decisions must be subject to public comment and agency review. Perceptions that alternative dispute resolution does not complement the Procedural requirements of NEPA may block the application of alternative dispute resolution.

\section{Solution:}

In reality, alternative dispute resolution enhances and implements the spirit of NEPA by generating better consultation, cooperation, and coordination among interested parties. Procedures and policies may need to be examined to determine if they assist or hinder problem solving and dispute resolution.

6) Lack of understanding about alternative dispute resolution processes-Many people do not have an understanding of alternative dispute resolution or its application. Fear of the unknown can impede the application of alternative dispute resolution. In addition, poorly applied efforts of alternative dispute resolution can result in turning many people off to valuable problem and dispute resolution processes.

\section{Solution:}

Training and application will bring about knowledge and comfort with alternative dispute resolution processes. Recognizing the efforts of individuals and sharing of successes will help people to visualize how alternative dispute resolution can be applied in real life situations.

7) Fear of disappointing the desire for a strong advocate (Winner-take-all mentality)-Many groups and individuals entertain an attitude of "winner-take-all" in public land planning. Some may fear that alternative dispute resolution will be too soft a stand. This mentality may stem from the "hired gun" attitude which stresses defeating the other side as the primary objective. Reputations of some consultants and special interest groups are founded on that of a tough litigator rather than an effective problem solver. Other factors may be: outside counsel may fear losing authority and control; some may feel that the maximum recovery is not obtained; a group or individual may not accept that alternative dispute resolution can be a beneficial option and some may be unwilling or unable to perceive the merit of the other side's position.

\section{Solution:}

This attitude makes a fundamental mistake in assuming that alternative dispute resolution processes are a weak case. With $78 \%$ success rate in cases examined, evidence suggests that alternative dispute resolution strategies are indeed a strong case for settling disputes. In addition, the level of implementation of agreements has been improved through alternative dispute resolution processes. Showcase examples and experience with alternative dispute resolution can bring about an attitude change in those who really do want to solve problems and manage resources. Professional trouble makers and so called "hired guns" may seek other avenues to carry out their conflict generating agendas.

8) Giving up on the ability to reach agreement-Within some 
organizations there is a perceptual resignation that settlements and applied management cannot occur outside of court-directed rulings. There is a notion that the opposition can be made to conform to a value or position through litigation. In reality, these strategies have largely failed to generate a desired outcome. Appeals, court suits, stonewalling and refusals to conform often result.

\section{Solution:}

Demonstrations and published documentation of implemented alternative dispute resolution generated agreements will help lay these fears to rest. Support from agency supervisors and administrators will help employees feel that alternative dispute resolution techniques are valuable and acceptable.

\section{Summary}

Interest in alternative dispute resolution processes in public land planning is increasing. As persons involved in natural resource conflicts become frustrated with traditional dispute resolution processes, they are looking more intently at alternative conflict management strategies. Today, there are several major factors that hinder the application of alternative dispute resolution processes in public land planning. These factors will be overcome as more people become aware of the benefits of alternative dispute resolution. Showcases will demonstrate that alternative dispute resolution processes complement federal land management policies and guidelines.

The potential exists for alternative dispute resolution to create a new paradigm in public land planning and management. Public land management professionals who use alternative dispute resolution will come to see the technologies of the behavioral and social sciences as valuable as they do the biological sciences for solving range management issues. They will come to understand that alternative dispute resolution processes enhance the level of effective decision making and implementation of agreements in public land planning and management.

\section{Literature Cited}

Bingham, G. 1986. Resolving environmental disputes, a decade of experience. The Conservation Foundation, Washington, D.C. p. 73.

Priscoli, J.D. 1990. From Hot-Tub to War: Alternative Dispute Resolution (Alternative Dispute Resolution) In: .S. Corps of Engineers. Proc. Engineering Foundation Conference. Santa Barbara, Calif.

Lancaster, C.L., M.S. Millhauser, S. Lingenfelter, and R.M. Bunker. 1990. Alternative dispute resolution round table. U.S. Army Corps of Engineers. Alternative Dispute Resolutions Series. IWR Working Paper 90-ADR-WP1.

Moore, C., and J.D. Priscoli. 1989. The executive seminar on alternative Dispute resolution (ADR) procedures. Prepared for and with the U.S. Army Corps of Engineers by CDR. Assoc. 